\title{
A FUNÇÃO SOCIAL E SOLIDÁRIA DA EMPRESA NO ÂMBITO DAS RELAÇÕES DE TRABALHO
}

\section{THE SOCIAL FUNCTION OF THE COMPANY AND SOCIAL SOLIDARITY IN THE AREA OF LABOR RELATIONS}

\author{
Jordana Viana Payão ${ }^{1}$ \\ Mariana Ribeiro Santiago ${ }^{2}$
}

\section{Resumo}

O presente artigo abordará os efeitos da introdução no ordenamento jurídico brasileiro da supremacia do valor da dignidade da pessoa humana, por meio da Constituição Federal de 1988, diante do atual cenário econômico capitalista globalizado. Destacando a atuação empresarial como palco primordial dos conflitos entre interesses meramente econômicos e privados e os direitos sociais fundamentais do ser humano, demonstra-se que a solidariedade não somente como valor subjetivo do ser humano, mas como mecanismo concretizador de direitos e garantias fundamentais. A esfera dos direitos trabalhistas ganha destaque no que se refere á violação da função social/ solidária empresa, já que a proteção aos direitos trabalhistas e, conforme restará demonstrado ao longo do estudo, a erradicação da exploração da mão de obra análoga a de escravo é fator primordial do desenvolvimento da solidariedade empresarial. Os métodos utilizados na abordagem da temática foram o dialético-jurídico e histórico, conjuntamente à pesquisa bibliográfica.

Palavras-chave: Empresa; Função Social; Solidariedade; Relações de trabalho; Mão-de-obra escrava.

\begin{abstract}
This article will address the effects of introducing the Brazilian legal system of the supremacy of the value of human dignity, through the Federal Constitution of 1988, before the current global capitalist economic environment. Highlighting the business activity as the primary stage of the conflict between purely economic and private interests and the fundamental social rights of human beings, we demonstrate solidarity not only as subjective value of the human being, but as concretizing mechanism of fundamental rights and guarantees. The sphere of labor rights is highlighted as regards the violation of the social function / joint company, since protection of labor rights and as remain demonstrated throughout the study, the eradication of exploitation of similar labor slave to it key factor in the development of corporate solidarity. The methods used in the thematic approach were the dialectical-legal and historical, together with research os literature.
\end{abstract}

Keywords: Enterprise; Social role; Solidarity; Work relationships Labor; Slave labor.

\footnotetext{
${ }^{1}$ Mestranda em Direito na Universidade de Marília - UNIMAR. E-mail: mariana@nbsadvogados.com.br

2 Doutora em Direito pela Pontifícia Universidade Católica de São Paulo - PUCSP. Professora do Programa de Mestrado em Direito da Universidade de Marília - UNIMAR. Editora-chefe da Revista Argumentum. E-mail: mari.santiago@terra.com.br
} 


\section{INTRODUÇÃO}

A ordem constitucional inaugurada pela Carta Magna de 1988 possui, dentre outros méritos, o do reconhecimento da dignidade da pessoa humana e da solidariedade social como pilares da sociedade, os quais ecoam nos mais diversos ramos do direito e da comunidade com um todo.

Diante desse quadro, a dignidade da pessoa humana e a solidariedade social foram alçados à qualidade de vetores incontestes, e, consequentemente, o cenário econômico precisou adequarse aos novos valores e princípios inseridos pela ordem constitucional estabelecida.

O ideal puramente liberal cedeu espaço ao social, de modo a efetivar direitos e garantias fundamentais trazidos pela constituição e passíveis de serem reivindicados pelos seus titulares. 0 Estado assume o papel de garantidor destes direitos e garantias, de modo a proporcionar o mínimo de condições para a sobrevivência digna ao ser humano, incluindo-se aí a educação, saúde, lazer, alimentação, pleno emprego etc.

Porém, diante das infindáveis necessidades da sociedade, o Poder Público, de forma isolada, não obtém êxito na concretização plena de tais premissas, em face das limitações orçamentárias a que está sujeito, fato público e notório.

Surge, então, a necessária interação com o âmbito privado na efetivação dos direitos e garantias fundamentais, ou seja, a conscientização da iniciativa privada de que é preciso contribuir com os aspectos sociais, educacionais e até culturais da comunidade em que está inserida.

As questões que sobrevêm são: qual a relação da função social da empresa e da solidariedade social com o direito do trabalho? Quais os efeitos de uma atuação pró-sociedade da empresa para seus empregados? Como compatibilizar interesses puramente econômicos às necessidades da classe trabalhadora?

O presente estudo visa abordar uma das vertentes influenciadas diretamente pelo primado da dignidade da pessoa humana e solidariedade social, qual seja, a função social e solidária da empresa perante os direitos dos trabalhadores. Para tanto, a abordagem utilizada é a dialéticajurídica, combinada com a pesquisa bibliográfica.

Nesse sentido, cumpre desenvolver uma passagem pelos períodos históricos do direito empresarial, com suas tendências e evoluções, para, na sequência, enfrentar a temática da função social e da solidariedade social, e, por fim, relacionar tais ideias ao direito do trabalho. 


\section{ASPECTOS HISTÓRICOS DA EMPRESA}

O direito empresarial, em uma primeira fase, consistia no direito aplicável aos membros de determinada corporação de comerciantes. A partir do século XIX, na França, surge o Código Comercial (1808), com adoção da chamada teoria dos atos de comércio, que estabelecia, basicamente, que aquele que explorasse atividade econômica considerada pelo direito como ato de comércio ou mercancia (compra e venda, indústria, bancos e seguro) estaria sujeito às normas do referido diploma (COELHO, 2014, p. 28).

A teoria dos atos de comércio, diante de suas restrições, foi insuficiente na regulamentação de todas as atividades consideradas comerciais com o decorrer do tempo. Com o desenvolvimento acentuado da economia, no século XIX, auge da Revolução Industrial, a visão do direito comercial volta-se à atividade empresarial de uma forma ampla, dando abertura para o surgimento da teoria da empresa, em 1942, na Itália.

A teoria da empresa amplia o campo de atuação do direito comercial, incorporando atividades até então excluídas pela teoria dos atos de comércio, deixando de dividir as atividades econômicas em dois grandes grupos, civil e comercial, mas prevendo de forma ampla, as atividades econômicas, a exceção das atividades intelectuais, de natureza literária, artística ou científica (COELHO, 2014, p. 29).

Em 1850, no Brasil, é promulgado o Código Comercial, fortemente influenciado pela teoria dos atos de comércio. Porém, a entrada em vigor do atual diploma civil, no ano de 2002, promoveu a unificação das obrigações civis e comerciais, pela influência italiana, e os ideais da teoria da empresa foram abarcados pelo âmbito empresarial.

Na realidade, como ressalta Miguel Reale (1986, p. 6), essa unificação já se observava há muito tempo na prática, em virtude da antiguidade do Código Comercial. A atividade empresarial é na verdade uma especificação do direito das obrigações, uma projeção natural e imediata deste. É por essa razão que o direito de empresa (Livro II) surge no Código de 2002 como conseqüência imediata do direito das obrigações (Livro I).

A unificação do direito das obrigações, entretanto, não é novidade no panorama jurídico nacional, já havia sido proposta no Esboço de Código Civil de Teixeira de Freitas (de 1864), além do que não segue à risca o modelo italiano, que estende a unificação ao campo do direito do trabalho.

O Código de 2002 revogou a parte primeira do Código Comercial (arts. 1--456). A parte terceira (arts. 797-913) já havia sido revogada pela Lei de Falência. Em relação ao Código Comercial, atualmente só está em vigor a sua parte segunda, que trata do comércio marítimo, com 
exceção do título IX (Do naufrágio e salvados - arts. 731/739), anteriormente revogado pela Lei 7.542/86, em vigor ${ }^{3}$.

De acordo com Rubens Requião (1978, p. 32), a empresa, em síntese, no sentido econômico, pode ser definida como uma organização de fatores de produção.

Por esse conceito, uma vez que a empresa está inserida na ordem econômica, como agente organizador da atividade produtiva e gestora de propriedades privadas, conclui-se que a limitação constitucional que condiciona a livre iniciativa e a propriedade a uma função social repercute diretamente na empresa, impondo-Ihe também uma função social, à semelhança do que ocorre com o contrato.

A esse respeito, vale lembrar a lição de Jaime Santos Briz (1966, p. 26), para quem:

la libertad de industria en sentido amplio (como libertad de creación de empresas y libertad de economía) encierra la libertad de competencia, la libertad de contratación, la de producción y la de consumo.

Nas palavras de Fábio Ulhoa Coelho (2014, p. 24), a atividade empresarial, objeto de estudo do direito empresarial, pode ser considerada como:

A articulação de fatores de produção, que no sistema capitalista são quatro: capital, mão de obra, insumo e tecnologia. (...) estruturar a produção ou circulação de bens ou serviços significa reunir os recursos financeiros (capital), humanos (mão de obra), materiais(insumo) e tecnológicos que viabilizem oferecê-los ao mercado consumidor com preços e qualidade competitivos.

Ao longo do tempo, os princípios norteadores da atividade empresarial, antes pautados primordialmente na lucratividade como finalidade única da empresa, evoluíram e continuam a evoluir, em direção a uma amplitude superior a tudo o que era tido por "empresa".

Considerar a mão de obra como mero fator de produção ou mecanismo operacional para produção e circulação de produtos e serviços e, conseqüente, obtenção de lucro já não parece tão apropriado perante as novas premissas traçadas pelos direitos garantias fundamentais previstos na Constituição.

Nesse sentido, o papel desempenhado pelas empresas neste século deve transcender o ideal exclusivamente lucrativo, uma vez que, atualmente, o cunho social representado por estas atinge muito mais a sociedade que própria atividade econômica desenvolvida (OLIVEIRA e SANTOS, 2016).

É clarividente a transição do direito empresarial de um patamar eminentemente privado em direção a ideais voltados também ao coletivo. O perfil do empresário bem sucedido já não se

\footnotetext{
${ }^{3}$ Atualmente tramita no Congresso o Projeto de Lei 1.572/2011, o qual prevê a implementação de um novo Código Comercial.
} 
resume aquele com maior competitividade no mercado ou cujo patrimônio é mais robusto, mas passa a ser valorizada aquela empresa com iniciativas socais, educacionais e culturais, ou seja, que agreguem á comunidade como um todo.

Pois bem, a construção de um ambiente corporativo voltado também às contingências sociais está em andamento. A conscientização de que a busca pelo lucro precisa ser relativizada perante as fragilidades humanas do semelhante ainda é prematura, porém, o reconhecimento da função social e solidária da empresa é ponto essencial nessa luta, conforme será tratado a seguir.

\section{FUNÇÃO SOCIAL DA EMPRESA}

Redefinidos pela ordem constitucional inaugurada em 1988, os pilares do direito privado (autonomia da vontade e a propriedade) são inspirados agora pelo paradigma da função social e da solidariedade, tendo em vista a busca pela justiça distributiva e social como fim do princípio da dignidade da pessoa humana.

O exercício do próprio direito individual, no caso o direito de explorar uma atividade econômica (livre iniciativa), na perspectiva da nova ordem constitucional, só é legítimo quando se coaduna com o interesse social.

A ordem econômica constitucional, conforme prevê o artigo 170, da Carta Magna, possui como fundamento a valorização do trabalho humano ao lado da livre iniciativa e visa garantir a todos a existência digna, nos ditames da justiça social, pautada, ainda, nos seguintes princípios, dentre outros: função social da propriedade, defesa do meio ambiente e a busca do pleno emprego.

O dispositivo constitucional não poderia ser mais claro quanto aos pilares privilegiados pela ordem constitucional, quais sejam, essencialmente, a dignidade da pessoa humana e a solidariedade social, que se irradiam em todos os aspectos da ordem econômica atualmente.

No Brasil, a função social foi inserida no texto constitucional de 1946, em detrimento da propriedade, que pioneiramente estabeleceu a possibilidade de desapropriação por interesse social, ainda que não houvesse a expressão literal "função social", fato que só ocorreu na Carta de 1967, prevista como um dos princípios da ordem econômica e social a função social da propriedade 4 .

\footnotetext{
${ }^{4}$ A função social da propriedade repercute diretamente na atividade que é desenvolvida na propriedade, logo, emerge disso a função social da empresa. Em que pese a doutrina majoritária não identificar uma dicotomia entre os dois institutos, considerando que a função social da empresa de fato decorre da função social da propriedade, interessante citar o apontamento de Rafael Vasconcellos Pereira: "é importante
}

Revista de Direito da Cidade, vol. 08, no 3. ISSN 2317-7721 pp.1120-1136 1124 
Enfim, com o advento da Constituição de 1988 houve uma previsão mais abrangente, conforme os dispositivos 5ㅇ, caput e inciso XXII, e 170, inciso II e III. A partir daí, todo o ordenamento jurídico pretendeu adequar-se à nova premissa trazida pela função social. Por exemplo, o artigo 1228, § 10, do Código Civil de 2002, dispôs que a propriedade deverá estar em consonância com a finalidade social, bem como, no que se refere aos contratos, o artigo 421 materializa o princípio da função social.

Celso Antônio Bandeira de Mello (2011, p. 930) teceu comentários a respeito da temática, no seguinte sentido:

Numa primeira acepção, considerar-se-á que a "função social da propriedade" consiste em que esta deve cumprir um destino economicamente útil, produtivo, de maneira a satisfazer as necessidades sociais preenchíveis pela espécie tipológica do bem ( ou pelo menos não poderá ser utilizada de modo a contrariar esses interesses), cumprindo, destarte, ás completas sua vocação natural, de molde a canalizar as potencialidades residentes no bem em proveito da coletividade (ou, pelo menos, não poderá ser utilizada de modo a adversá-las).

A função social da empresa possui o mesmo sentido, ou seja, a empresa deve cumprir com as finalidades principais para as quais fora estruturada, uma vez que são úteis ao desenvolvimento econômico do país. Por outro lado, não pode atuar inerte á realidade social, educacional, cultural do meio em que se encontra, devendo contribuir com o cumprimento dos direitos e objetivos constitucionais, que, por óbvio, vão além do estatuto da empresa.

O termo "função social" padece de certa indeterminação propositalmente utilizada pelo Direito contemporâneo com a finalidade de permitir a amplitude de interpretação, direcionando o direito privado aos objetivos fundamentais da República, atualizando-o, outrossim, às transformações dos valores adotados pela sociedade, de maneira que ela tem a vantagem de tornar o Direito privado um sistema flexível, voltado ao atendimento dos direitos fundamentais num sentido concreto (CARDOSO, 2013, p. 201).

Pode-se afirmar, consequentemente, que limitar a empresa através de sua sociabilidade ou função social significa a democratização e moralização do governo da empresa e a realização de uma conduta que atenda aos superiores interesses do país e da sociedade (WALD, 2003, p. 854).

realçar o caráter independente da função social da empresa em relação ao princípio da função social da propriedade privada, equivocadamente compreendido aquele como decorrência deste. Pois, da análise simples do ordenamento jurídico, conclui-se pela perfeita autonomia lógico-legal de ambos os princípios, até porque a empresa é sujeito de direito e sua atividade que deve ser exercida com observância da função social (Função Social da empresa. DireitoNet, 19/11/2015. Disponível em: < http://www.direitonet.com.br/artigos/exibir/1988/Funcao-social-da-empresa>.). 
Maria Helena Diniz (1998, p. 613) define a função social da empresa como:

O exercício pelo administrador da sociedade por ações das atribuições legais e estatutárias para a consecução dos fins e do interesse da companhia, usando do seu poder de modo a atingir a satisfação das exigências do bem comum.

No mesmo sentido, Eduardo Tomasevicius Filho (2003, p. 40) afirma que a função social da empresa constitui um poder-dever por parte do empresário e dos administradores da empresa de harmonizarem as atividades desta com o interesse da sociedade, mediante a obediência de determinados deveres positivos e negativos.

Uma vez imprimido pela Ordem Constitucional a prevalência da Dignidade da Pessoa Humana perante os demais direitos, em especial, os iminentemente individuais, gera a conscientização de que a atuação do particular pode repercutir na órbita dos direitos da coletividade, ainda mais quando a capacidade econômica que detém lhe permite atuar de modo egoístico e indiferente em relação aos demais membros da sociedade.

A função social visa compatibilizar os interesses individuais aos interesses coletivos, afinal, o Estado, de maneira isolada, não consegue atender a todas as demandas sociais. Logo, a função econômica, financeira e competitiva da empresa deve coadunar-se á função eminentemente social.

Em contrapartida, o ambiente empresarial possui estrutura, capital e pessoal capacitado para o desenvolvimento de projetos bastante vantajosos para o coletivo, que estão além da sua função social, mas se coadunam perfeitamente com a ideia de solidariedade social, do que a sociedade não pode prescindir, conforme será analisado a seguir.

\section{FUNÇÃO SOLIDÁRIA DA EMPRESA}

A Constituição Federal estabelece, no artigo 3o, os objetivos da República Federativa do Brasil, dentre os quais, no inciso I, "construir uma sociedade livre, justa e solidária".

Na condição de Constituição dirigente que é, prevê ideais a serem perseguidos por toda a sociedade, na concretização de tais objetivos republicanos. Eros Grau (2015, p. 212), interpretando o dispositivo, aduz que:

Sociedade livre é sociedade sob o primado da liberdade, em todas as suas manifestações, e não apenas enquanto liberdade formal, mas sobretudo como liberdade real. Liberdade da qual, neste sentido, consignado no art. 3ำ, I, é titular- ou cotitular, ao menos, paralelamente ao indivíduo- a sociedade. Sociedade justa é aquela, na direção do que aponta o texto constitucional, que realiza 
justiça social, sobre cujo significado adiante me deterei. Solidária, a sociedade que não inimiza os homens entre si, que se realiza no retorno, tanto quanto historicamente viável, á Geselchaft- a energia que vem da densidade populacional fraternizando e não afastando os homens uns dos outros.

Comentando o art. 3ำ, I, da Constituição brasileira, José Afonso da Silva (2009, pp. 46-47) assevera:

O que a Constituição quer, com esse objetivo fundamental, é que a República Federativa do Brasil construa uma ordem de homens livres, em que a justiça distributiva e retributiva seja um fator de dignificação da pessoa e em que o sentimento de responsabilidade e apoio recíprocos solidifique a ideia de comunidade fundada no bem comum. Surge aí o signo do Estado democrático de direito, voltado à realização da justiça social, tanto quanto a fórmula liberdade igualdade e fraternidade o fora no Estado liberal proveniente da Revolução Francesa.

Ao tentar precisar o alcance da palavra solidariedade, Paulo Luiz Netto Lôbo (2009, p. 81) afirma que esta,

Como categoria ética e moral que se projetou para o mundo jurídico, significa um vínculo de sentimento racionalmente guiado, limitado e autodeterminado que impõe a cada pessoa deveres de cooperação, assistência, amparo, ajuda e cuidado em relação às outras. A solidariedade cresce de importância na medida em que permite a tomada de consciência da interdependência social.

A solidariedade social realiza-se, então, como um ato complexo, no qual concorrem o Poder Público e a própria sociedade, apontando a Constituição Federal as diretrizes ideológicas, políticas e jurídicas para sua otimização e implementação, ao acolher os princípios da dignidade humana e do pluralismo social e político (DINIZ, 2007, p. 173).

O desenvolvimento econômico no cenário globalizado atual fomenta a competividade e a busca incessante pelo lucro, em especial no âmbito corporativo, onde a regra é redução de custos e elevação de capital. A consciência social perde espaço diante do interesse puramente econômico que prevalece nas atividades empresariais, acentuado pelo individualismo exacerbado que faz desaparecer sentimentos fraternos e solidários.

Aspectos injustos da modernidade trouxeram a miséria, a desigualdade e a injustiça social, passando o Estado a assegurar e prevenir tais riscos sociais, mediante sistemas de proteção de trabalho e regimes de previdência, pautados em ditames de solidariedade social.

Para mudar essa situação de individualismo e, consequentemente, de desagregação social, o princípio da solidariedade, antes que isso um valor, ingressa no sistema jurídico como uma forma de atribuir significado ao próximo, correlacionando-se a um modo de despertar a intencionalidade 
humana em reconhecer a existência do outro, porque conduz o comportamento á consciência perceptiva do seu ambiente social (CARDOSO, 2013, p. 157).

Alenilton Cardoso diferencia os direitos da solidariedade do princípio da solidariedade, os primeiros consistem nos direitos sociais, econômicos e culturais previstos pela Constituição Federal, devendo ser implementados pelo Estado como garantia à dignidade da pessoa humana. São chamados pela doutrina como direitos fundamentais de terceira geração, tais como, o direito ao meio ambiente sadio, direito á paz etc. (2013, p. 157).

O princípio da solidariedade, segundo o referido autor, é mais amplo, já que não se limita ao vínculo do Estado perante à sociedade, mas entre os indivíduos integrantes da sociedade e seus pares e o Estado, na esfera ética, política, econômica, cultural, jurídica etc (CARDOSO, 2013, p. 157).

Fraternidade e solidariedade não são sinônimos, mas complementam-se, pois, enquanto a segunda se exprime nos variados modos de auxilio ao semelhante e de agir em conjunto ao próximo, a primeira é mais abrangente, expressando valores como amor, tolerância e respeito ao outro, bem como, um agir em benefício ao próximo, altruísmo mesmo, filantropia (GRECO, 2005, p. 174).

José Casalta Nabais (2005, p.112) em análise da solidariedade expõe que :

(...) Daí também que a solidariedade, enquanto fenômeno estável ou duradouro e mais geral, se refira á relação ou sentimento de pertença a um grupo formação social, entre os muitos grupos ou formações sociais em que o homem manifesta e realiza atualmente sua affectio societatis, dentro dos quais sobressai naturalmente a comunidade paradigma dos tempos modernos - o Estado. Do que resulta que a solidariedade pode ser entendida quer no sentido objetivo, em que se alude á relação de pertença e, por conseguinte, de partilha e de co-responsabilidade que liga cada um dos indivíduos á sorte e vicissitudes dos demais membros da comunidade, quer em sentido subjetivo e de ética social, em que a solidariedade exprime o sentimento, a consciência dessa mesma pertença á comunidade.

A ideia de solidariedade expressa a empatia perante as dificuldades do próximo, ou seja, a conscientização de que esforços mútuos são frutíferos, que não cabe exclusivamente ao Estado suprir necessidades sociais, até por ser tarefa inviável, logo, o papel do cidadão individualmente considerado e mais ainda, organizado em instituições privadas, ganha destaque e relevância social. Ultrapassa a filantropia ou a caridade, alcança mais do que meras ações sociais.

A cidadania solidária torna-se um aspecto fundamental nesse sentido, quando o cidadão assume um novo papel, ciente de que seu protagonismo ativo na vida pública já não se limita ao controle do exercício dos poderes estatais. Mas, acima de tudo, alcança a assunção de 
responsabilidades, encargos e deveres que derivam dessa mesma vida pública e que ultrapassam a competência exclusiva do Estado (NABAIS, 2005, p.112).

A empresa desenvolve papel fundamental nesse sentido, na condição de combustível da economia do país, não deve ficar limitada ao seu fim primordial que é a busca pelo lucro, mas possuir vetores de atuação voltados às necessidades sociais, conforme sua capacidade, seja no âmbito local, seja em maior abrangência.

A função solidária da empresa expressa justamente a junção dos conceitos de solidariedade e cidadania na atividade econômica, ao lado da função social da empresa, busca uma atuação mais humana na atividade empresarial, uma atuação mais positiva, com ações concretizadas.

Sob a ótica dos contratos, porém, útil à compreensão da temática da solidariedade, Lívia G. B. Campello e Mariana R. Santiago (2015) explicam que não se deve confundi-la com os conceitos de boa-fé objetiva e função social dos contratos. A função social dos contratos obriga os contratantes a não se afastarem das expectativas sociais, referentes a um dado negócio, não se desviando para propósitos inúteis ou contrários à coletividade, sob pena de se observar a interferência estatal na readequação do negócio. O princípio da solidariedade nos contratos possui uma conotação diversa, pois agrega uma ideia de que se deve também colaborar, por meio do negócio, para o desenvolvimento da sociedade, numa perspectiva de auxílio às pessoas, de uma forma positiva, inclusive sob o ângulo das gerações futuras.

Ou seja, realizando um paralelo com o direito de empresa, as atividades empresariais devem proporcionar melhorias de variada ordem no meio social. Além da geração de empregos e circulação de bens e serviços, deve contribuir ao desenvolvimento social, melhoria das condições ambientais e urbanas da região em que se encontra, realizando investimentos na esfera educacional etc. O campo de atuação é vasto e carente de dedicação nesse sentido.

Logo, o espectro trabalhista é essencial à saúde empresarial. O respeito à dignidade humana dos trabalhadores é o mínimo que se espera dos empregadores. Porém, no aspecto interno da função solidária da empresa, e uma vez que toda atividade econômica atinge os mais diversos setores da sociedade, a atuação conforme os ditames da solidariedade deve ultrapassar o âmbito interno das pessoas jurídicas, alcançando a realidade social como um todo.

No geral, a função solidária da empresa agrega a função social, alcança a proteção ao meio ambiente, mediante o desenvolvimento de ações sustentáveis, a instituição de projetos sociais conforme a necessidade da região em que se encontra a empresa, enfim, ressalta a essencial atuação proativa da corporação com aspectos humanos, mediante investimentos em áreas 
diversas da meramente lucrativa. Nesse sentido Manoel de Queiroz Pereira Calças e Simone Bento (2015) explicam:

\begin{abstract}
A empresa pode agir com responsabilidade solidária direcionando suas ações para seus próprios empregados, como, por exemplo, ensejando boas condições no local de trabalho, conforto, qualidade de material, segurança, salários justos e incentivadores, plano de carreira, treinamento tecnológico, atividades educacionais, culturais e de lazer, contratação de deficientes e idosos. As ações da empresa podem também se dirigir aos familiares de seus empregados, fornecendo clubes para lazer e prática de esportes, creches, escolas, planos de saúde, educação continuada etc. O respeito aos direitos humanos como não exploração de mão-de-obra infantil, não utilização do chamado trabalho escravo, adoção de conduta baseada na igualdade das pessoas, sem levar em conta a diferença de sexo, religião, nacionalidade ou raça.
\end{abstract}

Ao que parece a solidariedade consiste em uma possível solução para uma sociedade desigual e injusta, mediante o reconhecimento do valor absoluto da dignidade da pessoa humana e seus direitos fundamentais, dos preceitos de Justiça distributiva e social, e, consequentemente, da funcionalização dos institutos de direito privado.

A função solidária da empresa ultrapassa os deveres a serem cumpridos pela empresa, conforme estabelece a legislação ou o próprio estatuto, mas repousa naquelas iniciativas voluntárias e que representem um impacto diferenciado na comunidade. Deve, nesse sentido, exteriorizar o sentimento de solidariedade, de visão do próximo propriamente dito.

\title{
REFLEXOS DO NOVO PAPEL DA EMPRESA NAS RELAÇÕES DE TRABALHO
}

O impacto da globalização na esfera empresarial é inquestionável, porém, os efeitos experimentados nas relações de emprego merecem atenção. O mercado econômico atual desconhece fronteiras, tanto pelos avanços tecnológicos, como pela inter-relação natural entre os países ao redor do globo. Em decorrência disso, foi acentuada a competitividade empresarial na conquista de mercados.

Note-se um cenário de reestruturação produtiva dentro das empresas, em que a regra é a redução de custos e a otimização da produção para a majoração dos lucros. O impacto no âmbito trabalhista é brutal, desencadeando o desemprego estrutural, dando espaço á informalidade como estratégia de redução de gastos, além de produzir ambientes de trabalho nocivos, com trabalhadores atuando mediante pressão e competitividade.

A preocupação com o meio ambiente de trabalho é tipicamente pós-moderna, posto que, com a intensa urbanização e industrialização, multiplicaram-se os acidentes de trabalho e as doenças profissionais, sejam de natureza física ou psíquica. Diante disso, uma contingência 
aparentemente interna da empresa passa à responsabilidade da sociedade, por meio dos auxílios e aposentadorias da Previdência Social.

É dentro dessa lógica que, ao tratar das atribuições do Sistema Único de Saúde, a Constituição Federal, no seu artigo 200, VIII, estabelece a obrigação de colaborar na proteção do meio ambiente, nele compreendido o meio ambiente do trabalho.

Fora isso, a qualificação internacional do direito ao meio ambiente como direito fundamental, nos termos da Declaração de Estocolmo de 1972, reafirmada pela Declaração do Rio de Janeiro de 1992, deixa evidente a magnitude do tema ora tratado, com clara conexão, ainda com os princípios da dignidade humana e da solidariedade social.

De acordo com Celso Antônio Pacheco Fiorillo (2010, p. 73)., o meio ambiente do trabalho pode ser definido como

O local onde as pessoas desempenham suas atividades laborais, sejam remuneradas ou não, cujo equilíbrio está baseado na salubridade do meio e na ausência de agentes que comprometam a incolumidade físico-psíquica dos trabalhadores, independentemente da condição que ostentem (homens ou mulheres, maiores ou menores de idade, celetistas, servidores públicos, autônomos etc.).

A própria Carta Constitucional reconheceu, ainda, o valor social do trabalho como fundamento da República Federativa do Brasil (artigo $1^{\circ}$, IV), tornando indissociável a exploração de uma atividade econômica com a responsabilidade social da empresa (artigo 170). Porém, há ainda um longo caminho a percorrer até que o país atinja o padrão idealizado pelo legislador constituinte.

Nesse contexto, o empregador não é responsável apenas pelo cumprimento das obrigações trabalhistas legais, como a quitação dos salários, férias, horas extras ou concessão de intervalor para descanso, mas também por garantir um ambiente de trabalho sadio, dinâmico e que proporcione ao empregado condições dignas de desenvolvimento.

No Brasil, em que pese a abolição centenária da escravidão, ainda há registros de exploração dos trabalhadores em regime de escravidão. Apenas em 2013, por exemplo, o Ministério Público instaurou 702 procedimentos para apurar denúncias de casos de trabalhadores em condições análogas à escravidão (submissão a trabalhos forçados ou a jornada exaustiva; condições degradantes de trabalho; restrição, por qualquer meio, de locomoção em razão de dívida com o empregador ou preposto) no País. ${ }^{5}$

\footnotetext{
${ }^{5}$ MINISTÉRIO PÚBLICO FEDERAL. MPF apresenta dados do combate ao trabalho escravo no Brasil. Disponível em < http://www.prpa.mpf.mp.br/news/2014/mpf-apresenta-dados-do-combate-ao-trabalho-escravo-nobrasil> 08.03.2016.
} 
Costumeiramente esse tipo de mão de obra é empregada em atividades econômicas, desenvolvidas na zona rural, como a pecuária, a produção de carvão e os cultivos de cana-deaçúcar, soja e algodão. Nos últimos anos, essa situação também tem sido verificada em centros urbanos, especialmente na indústria têxtil, construção civil e mercado do sexo. ${ }^{6}$

Segundo dados do Ministério do Trabalho e do Emprego,em 2013, 2.063 trabalhadores foram resgatados de situação análoga a de escravo -1.068 estavam no meio urbano. No período, a pasta realizou 179 operações de fiscalização. Do total de resgatados, 278 trabalhadores eram estrangeiros, sendo 121 haitianos, 104 bolivianos, 45 paraguaios e oito peruanos, os demais eram brasileiros. $^{7}$

No âmbito rural, o setor sucroalcooleiro destaca-se negativamente nos índices de exploração da mão de obra escrava, a labuta por si só já é excessivamente árdua, ademais, com o aumento da produção para fazer frente á competitividade no mercado econômico, a média de extração por cortador de cana que em 1960 era de duas toneladas por dia é hoje doze toneladas por dia. O pagamento por produtividade comum nesse âmbito, transfere ao trabalhador a responsabilidade pelo ritmo de trabalho, o que é degradante tanto física quanto mentalmente. ${ }^{8}$

A exploração da mão de obra escrava viola frontalmente a dignidade da pessoa humana e, por consequência, toda a ordem constitucional. A mentalidade exclusivamente capitalista do empresariado encara o trabalhador como mercadoria, um aspecto típico do regime escravagista.

Após 15 anos de tramitação a PEC 438/2001, chamada PEC do trabalho escravo, foi aprovada pelo Congresso Nacional em 2014, que dá nova redação ao art. 243 da CF/88 e determina a expropriação da gleba onde for constatada a exploração de trabalho escravo, com a sua consequente destinação à reforma agrária, revertendo a área prioritariamente ao assentamento dos colonos que já trabalhavam na respectiva gleba.

Logo, perante a Constituição Federal, só é legitima a propriedade e a empresa destinadas ao cumprimento da função social.

Nesse sentido José Aparecido Camargo e Leda Maria Messias da Silva (2015) explicam que:

Daí que é fundamental um ambiente hígido em todos os aspectos, garantindo ao trabalhador uma existência digna conforme os ditames da justiça social, porque as relações e reações que nele e dele fluem, afetam, ou

\footnotetext{
${ }^{6}$ ONG Repórter Brasil, disponível em < http://escravonempensar.org.br/sobre-o-projeto/o-trabalho-escravono-brasil/> 08.03.2016.

7 MINISTÉRIO DO TRABALHO E EMPREGO. Disponível em: <http://www.brasil.gov.br/cidadania-ejustica/2014/05/apos-15-anos-pec-do-trabalho-escravo-e-aprovada-por-unanimidadem>08.03.2016.

${ }^{8}$ ONG Repórter Brasil. O trabalho escravo no Brasil. Disponível em <http://escravonempensar.org.br/sobre-oprojeto/o-trabalho-escravo-no-brasil/> 08.03.2016.
} 
podem afetar toda a sociedade, inclusive aqueles próximos ou integrantes do ambiente privado do trabalhador, sua família e outros no âmbito de sua intimidade.

A empresa não pode esquivar-se dessa responsabilidade de cunho nitidamente social, humano, ou seja, consiste em clara expressão da função social da empresa o fomento a práticas que valorizem o ambiente de trabalho. O reconhecimento do trabalhador como ser humano, ao invés de simples peça operacional da produção na empresa ou um aspecto mercadológico apenas, é inerente aos ditames constitucionais pautados na dignidade da pessoa humana.

A função solidária ultrapassa o ambiente corporativo interno, ou seja, o ideal é que as inciativas a favor do mercado de trabalho sejam desenvolvidas em benefícios da sociedade como um todo, não ficando restritas aos trabalhadores ligados diretamente à empresa. Nesse sentido, projetos de educação, lazer, cultura etc. devem ser acessíveis pelo maior público possível. Afinal, essa é a ideia da função solidária, ultrapassar limites corporativos e alcançar a comunidade.

No que se refere ás iniciativas educacionais, por exemplo, Carolina Vieira Mercante (2012, p. 107) expõe:

É prudente ressalvar que, sob a justificativa da constante necessidade de aperfeiçoamento do trabalhador e da polivalência dele exigida pelo mercado globalizado, o setor empresarial possui uma inclinação para desenvolver atividades ligadas ao desempenho dos empregados em seus locais de trabalho. No entanto, as iniciativas empresariais sofrem críticas de estudiosos na área da educação, por serem intensamente voltadas ao treinamento de funções restritas á atividade produtiva da empresa, aproximando-se de um adestramento do trabalho, e não de um ensino científico-tecnológico que o estimule á reflexão e ao pensamento crítico.

A empresa deve reconhecer o papel essencial que desempenha na construção da sociedade. Nessa linha, Anelinton Cardoso (2013, p. 289) assevera que:

O Direito Privado hodierno procurar dar á empresa a maior relevância social possível, pois a visão de um direito individualístico não favorece o desenvolvimento da sociedade, pelo contrário, conduz a injustiça cruel, o que foi pressuposto pelo constituinte originário do art. 170, caput, Lei Maior, ao positivar uma ordem finalística á livre inciativa econômica, a partir da noção de valorização social do trabalho, existência humana digna e Justiça social.

Existem diversos mecanismos de concretização da função social e solidária da empresa no âmbito trabalhista, como a inserção da pessoa portadora de deficiência, o investimento em um meio ambiente do trabalho saudável e plural, a participação dos empregados na divisão dos lucros e da gestão empresarial, conforme prevê o texto constitucional no art. 7ำ, inciso XI etc.

A gestão é relevante no aperfeiçoamento das relações empresariais, já que insere os empregados no conjunto administrativo e organizacional da empresa. O ambiente laboral interage 
com o sistema social mais amplo que integra, do qual recebe e sobre o qual exerce influências. Sendo assim, a responsabilidade social empresarial é indissociável da economia propriamente dita.

\section{CONCLUSÃO}

Conforme previsto na Constituição Federal, artigo 170, a valorização do trabalho humano ao lado da livre iniciativa fundamenta a Ordem Econômica, no objetivo de garantir a todos a existência digna, nos ditames da justiça social, pautada na função social da propriedade, defesa do meio ambiente e a busca do pleno emprego.

Logo, a compatibilização entre os interesses privados do empresariado e os interesses sociais que respaldam a justiça social é um desafio constante, e o direito de empresa, sempre voltado á produção e circulação de bens e serviços e, conseqüente, geração de lucro, deve voltarse a anseios menos mercadológicos, como cumprir com a função social e solidária.

O desenvolvimento de ações sociais voltadas à proteção do meio ambiente, ao repúdio do trabalho escravo, à inserção das pessoas portadoras de deficiência no mercado de trabalho, ao aperfeiçoamento educacional e profissionalizante dos cidadãos, bem como à manutenção de um ambiente de trabalho ético, harmonioso e saudável, consiste em apenas alguns dos mecanismos aptos a concretizar a nova ideologia que se estabeleceu no âmbito corporativo desde a ordem constitucional de 1988.

Junto ao fim primordial de qualquer empreendimento empresarial deve estar o fim maior, qual seja, a garantia ao valor da dignidade da pessoa humana, de modo a compactuar com a nova ordem constitucional. Não obstante as previsões constitucionais e infraconstitucionais, além da própria jurisprudência, falta ainda certa conscientização do empresariado da proporção da influência que possui na sociedade como um todo, além da aptidão que possui de transformação social. O mero cumprimento de obrigações legais nem se aproxima do ideal e do possível em termos de função social, solidariedade e humanidade, preceitos tão em falta em tempos de globalização e competição acirrada.

Ademais, a constatação de que a exploração de mão de obra escrava ainda é uma realidade no país é desoladora e clama por uma intervenção estatal enérgica, com duras punições patrimoniais e pessoais.

Em contrapartida, lançando mão da extrafiscalidade, como mecanismo de premiação às empresas que desenvolvam iniciativas de combate a tais práticas, o Estado pode auxiliar na 
efetivação da função social e solidária da empresa, o que seria extremamente salutar nos tempos atuais e suas demandas.

\section{REFERÊNCIAS}

BRIZ, Jaime Santos. La contratación privada: sus problemas en el tráfico moderno. Madri: Montecorvo, 1966.

CALÇAS, Manoel de Queiroz Pereira; BENTO, Simone. A Empresa: Responsabilidade Solidária e Sustentabilidade. Disponível em < http://www.publicadireito.com.br/artigos/?cod=674f3c2c1a8a6f90> Acesso em 13/11/2015.

CAMARGO, José Aparecido; SILVA, Leda Maria Messias da. O ambiente de trabalho e a integridade psicossomática do empregado. Disponível em: < http://www.josecamargo.com.br/images/Artigos_Autor/O_ambiente_de_trabalho_e_a_integridad e_do_empregado.pdf > Acesso em 16/11/2015.

CAMPELLO, Lívia Gaigher Bósio; SANTIAGO, Mariana Ribeiro. Função solidária: a terceira dimensão dos contratos. Disponível em <http://www.publicadireito.com.br/artigos/?cod=7283518d47a05a09 > 10.11.2015.

CARDOSO, Alenilton da Silva. Princípio da Solidariedade: O paradigma ético do Direito Contemporâneo. Ed. Ixtlan. São Paulo, 2013.

COELHO, Fábio Ulhoa. Manual de Direito Comercial. 26 ed. São Paulo: Saraiva, 2014.

DINIZ, Marcio Augusto de Vasconcelos. Estado social e o princípio da solidariedade. Nomos: Revista do Curso de Mestrado em direito da UFC. Fortaleza, v. 26, pp. 171-185, janeiro-junho de 2007.

DINIZ, Maria Helena. Dicionário jurídico. São Paulo: Saraiva, vs. 2-4, 1998.

FIORILLO Celso Antônio Pacheco. Curso de direito ambiental brasileiro. 11. ed. rev. atual. e ampl. São Paulo: Saraiva, 2010

GRAU, Eros Roberto. A ordem econômica na Constituição Federal de 1988. 17 ed. São Paulo: Malheiros, 2015.

GRECO, Marco Aurélio. Solidariedade social e Tributação. In: Solidariedade social e tributação. GRECO, Marco Aurélio; GODOI, Marciano Seabra de. (Coords.) São Paulo: Dialética, 2005.

LÔBO, Paulo Luiz Netto. Direito civil: parte geral. São Paulo: Saraiva, 2009.

MELLO, Celso Antônio Bandeira. Novos aspectos da função social da propriedade no direito público. In: Doutrinas Essenciais Direito Constitucional. CLEVE, Clemerson Merlim; BARROSO, Luís Roberto (coord). São Paulo: Revista dos Tribunais, Vol. VI, 2011. 
MERCANTE, Carolina Vieira. A responsabilidade social empresarial como meio propulsor da efetivação dos direitos trabalhistas. São Paulo: LTr, 2012.

NABAIS, José Casalta. Solidariedade Social, Cidadania e Direito fiscal In: Solidariedade social e tributação. GRECO, Marco Aurélio; GODOI, Marciano Seabra de (Coords.) São Paulo: Dialética, 2005.

OLIVEIRA, Lourival José de; SANTOS, Altair Cesar Ramos dos; BREDA, Francyni Shiavon; SANTAROSA, Lina Andrea. Função Social e Responsabilidade Social da Empresa nas relações de trabalho no Brasil. Artigo apresentado na IX ENINCE, publicado nos Anais. Disponível em http://www.faccar.com.br/eventos/enince/2010/anais2.php. Acesso em 14 março de 2016.

PEREIRA, Rafael Vasconcellos de Araújo. Função Social da empresa. Disponível em: < http://www.direitonet.com.br/artigos/exibir/1988/Funcao-social-da-empresa>. Acesso em 19.11.2015.

REALE, Miguel. O projeto de Código Civil: situação atual e seus problemas fundamentais. São Paulo: Saraiva, 1986.

REQUIÃO, Rubens. A co-gestão: a função social da empresa e o Estado de direito. Revista Forense, São Paulo, a. 74, v. 262, pp. 31-39, abr.-jun./1978.

SILVA, José Afonso da. Comentário contextual à Constituição. 6. ed. atual., São Paulo: Malheiros, 2009.

TOMASEVICIUS FILHO, Eduardo. A função social da empresa. Revista dos Tribunais. São Paulo, a. 92, v. 810, pp. 33-50, abr. 2003.

WALD, Arnoldo. O empresário, a empresa e o Código Civil. In: FRANCIULLI, Domingos e al. (coord.). O novo Código Civil: estudos em homenagem ao Prof. Miguel Reale. São Paulo: LTR, pp. 838-855, 2003.

Trabalho enviado em 21 de março de 2016.

Aceito em 22 de maio de 2016. 